\title{
THE ROLE OF BUSINESS SIMILARITY IN JOINT VENTURE PERFORMANCE
}

\author{
Louise Hatfield \\ Shippensburg University \\ Shippensburg, PA \\ John A. Pearce II \\ Villanova University \\ Villanova, PA
}

\begin{abstract}
Business similarity between partners was found to be positively related to joint venture performance. This finding complements two past studies that also found a positive relationship between business similarity and performance. The strength of these findings is amplified by the fact that each of the three studies used a different method of measuring business similarity and employed a different performance measure. The positive relationship between business similarity and performance was strong enough and consistent enough that all three measurement schemes captured the phenomena.

This research illustrates that (1) self-assessment by partner firms allows the degree of business similarity to be captured and (2) that self-assessment is more reflective of reality than are traditional, coarse, categorical classification schemes. Business similarity varies in degree, a phenomenon not captured in traditional research which emphasizes a dichotomous choice of similarity (i.e., related or unrelated).

This study found key dimensions of business similarity in the joint venture environment to be geographic areas served, supplier base, distribution channels, and forms of advertising and promotion. These dimensions contrast with the traditional business domain items that have been tried in past research, of product technology, manufacturing process, and product purpose.
\end{abstract}

\section{Introduction}

Joint ventures are discrete entities created, owned, and influenced by two or more firms (parents/partners) that provide inputs to and share in the outcomes of the created entity. Joint ventures are one type of strategic alliance. Whereas joint ventures are equity-based, most other strategic alliances are non-equity arrangements, such as licensing agreements, research and development contracts, codevelopment agreements, customer-supplier partnerships, and technology sharing (Hennart \& Reddy, 1997; Inkpen \& Beamish, 1997; Mowery, Oxley \& Silverman, 1996; Park \& Russo, 1996; Pearce, 1997). 
The surge in appeal of joint ventures comes as a result of the globalization of industries and the increasingly complex and competitive nature of the rapidly changing business environment. More and more firms find it necessary or advantageous to cooperate with other firms in order to be competitive. Joint venturing is an important alternative entry mode to internal start-up and acquisition (Kogut, 1988). In a fast-paced, highly competitive environment, the internal start-up option is exceptionally costly in terms of resources and time, as are acquisitions which include an obligation to manage all that comes with an acquired firm (Kanter, 1989). Joint venturing is faster, more flexible, less risky, and less costly than internal start-ups and acquisitions, while increasing access to critical resources such as marketing, technology, raw materials and components, financial assets, managerial expertise, and political influence (Schillaci, 1987).

The increasing use and strategic importance of joint venturing, as well as its unfamiliar complexity, suggest the need to know more about how to effectively utilize this cooperative strategy option. The purpose of this research is to contribute to the knowledge on conditions prevailing at the initiation of a joint venture strategy. This study explores how business similarity between partners and business similarity between a partner and its joint venture contribute to partner goal achievement.

\section{Literature Review and Hypotheses}

\section{Joint Venture Performance}

Although joint venture duration, survival, liquidation, and partner stock price have also been utilized, managerial assessment (i.e., partner satisfaction or partner goal achievement) remains the most frequently used measure of joint venture performance. Most joint venture performance studies have used managerial assessments as perceptual measures of performance (Beamish, 1987; Blumenthal, 1988; Habib \& Burnett, 1989; Harrigan, 1988; Hatfield \& Pearce, 1994; Killing, 1983; Schaan, 1983).

While duration and survival offer insight into joint ventures, they do not measure performance. Although duration, survival and stability have been found to significantly correlate with overall partner satisfaction and joint venture performance (based on projections), the range of correlations (.29 to .60) suggest that these variables measure different phenomena (Geringer \& Hebert, 1991). Further, Gomes-Casseres (1987) identified several "adaptive" reasons for joint venture termination that are frequently overlooked in duration and survival studies: (1) dissolution due to partner's acquisition of new capabilities, (2) growth in a partner firm's network that leads to a change in the optimal ownership structure to exploit economies of scope, and (3) government policy changes. Thus, duration, survival, and stability appear to be unacceptable measures of performance because termination of a joint venture may be the result of success, failure, or environmental change. 
Liquidation or major reorganization, if due to poor performance, as used by Killing (1983), may be a better objective performance measure. However, the qualifier "if due to poor performance," in the case of a takeover or reorganization has referred to perception-based explanations. Liquidation appears to be an objective measure of failure because it indicates that the joint venture has insufficient value as an entity. In addition, divesture and shutdown have been used as indicators of failure in evaluating diversification strategies, including joint ventures (Porter, 1987). However, liquidation measures alone capture only a portion of the corporate failures and poor performers. Recognizing these deficiencies, joint venture researchers have relied heavily on the broad, but vague, measure of partner satisfaction.

Neither the objective performance measures - duration, survival, liquidation or reorganization - nor the managerial assessment measure of partner satisfaction explicitly consider the objectives or goals of the partners. Further, one partner's success criteria is often different from that of the other partner (Schaan, 1983). Partner goal achievement offers a means to address this diversity in success criteria in a more precise fashion than is possible with partner satisfaction, while maintaining breadth of coverage. Self-reported, perceptual measures permit the assessment of specific and disparate goals (Blumenthal, 1988; Harrigan, 1987; Hatfield \& Pearce, 1994).

In summary, non-financial performance criteria are widely used to measure joint venture performance. These measures correlate with more objective measures of performance, such as financial indicators, and liquidation or reorganization (Dess \& Robinson, 1984; Killing, 1983). Many objective financial measures are fraught with problems of data availability and lack of comparability due to different accounting methods, and may be confounded due to varying goals and priorities. We, therefore, join other researchers in the belief that managerial assessment is the most appropriate measure of joint venture performance (Blumenthal, 1988). Results of prior research suggest that the benefits of perceptual measures outweigh potential respondent bias.

Partner goal achievement is the primary dependent variable in this study. The measurement of partner goal achievement is an expansion on traditional, simple, and often assumed goals. It allows for nonfinancial performance assessment, the need for which has been noted in the joint venture (Anderson, 1990; GomesCasseres, 1989; Habib \& Burnett, 1989), strategic management (Fahey \& Christensen, 1986) and organizational effectiveness literature (Lewin \& Minton, 1986). Focusing on partner goals offers a way to deal with the performance evaluation problem when a partner firm has a broader base of interests than does the joint venture (Kanter, Richardson, North \& Morgan, 1991). In a study on joint venture partner goals, Hatfield \& Pearce (1994) illustrated that partner goal achievement provides an enriched understanding of joint venture performance.

Partner goal achievement overcomes the narrow focus of traditional financial measures, and the vagueness of the frequently used measure of partner satis- 
faction. Goal achievement offers more precision than partner satisfaction while maintaining breadth of coverage, by providing the ability to address partner goal diversity and divergent partner interests. Partner satisfaction is added as a supplemental dependent variable because of its usage in past joint venture research. This combination of dependent variables provides a bridge to past research and a basis of comparison for the preferred dependent variable in this study of partner goal achievement.

\section{Business Similarity}

To expand operations or profits faster and/or less expensively, businesses often seek to acquire a competing firm that displays business similarity. The strategy of buying market share may improve the performance of corporate assets through operational economies or reduced costs. Enhanced management capabilities and better utilization of capacity may follow the acquisition of a similar business. There also may be gains in efficiency due to the complementary capabilities of the joined forces that could not easily be accomplished through internal expansion (Weston \& Chung, 1983; Shepherd, 1985; Rock, 1987; Moose \& Richard, 1988).

Kusewitt (1985) examined the relationship between industry commonality and long term financial performance as measured by ROA and market returns in a study of 135 acquiring firms. He found that the two variables were positively and significantly related. He concluded that acquisitions should be of related business to enhance synergy and management effectiveness. Similarly, Singh \& Montgomery (1987) examined business similarity as an acquisition strategy in a study of 105 acquisitions of value greater than $\$ 100$ million each. They found that acquired firms involved in mergers of similar businesses have higher returns than acquired firms in unrelated acquisitions.

Production synergy is perhaps the most cited contributor to value maximization for a firm considering the acquisition of a similar business (Fisher $\&$ Lande, 1981). Proponents of this argument emphasize both scale and scope economies. Where these economies can be achieved, cost reductions ensue and true synergies exist (Carlton, 1980; Mueller, 1980; Shepherd, 1985; Singh \& Montgomery, 1987).

The acquisition of a similar business also promotes the achievement of production objectives when a firm wishes to supplement an already established distinctive competence in a product technology or manufacturing process (Hopkins, 1987). Technology transfer through the acquisition of a similar business allows firms to respond quickly to industry changes and increase its ability to innovate.

When the competitiveness of a firm is highly dependent of its geographic scope, it is usually more profitable to acquire an existing firm in another geographic location than to expand geographically through internal growth (Allen, Oliver \& Schwallie, 1981). Since distribution costs are generally proportional to distance shipped, marketing synergies often result in economies in transporting 
bulky materials. Thus, merged firms from different geographic locations shorten the average distance from one of their operations to customers.

Marketing synergy is likely to occur in the merging of similar firms when at least one product or service fortifies the sales of one or more others (Hopkins, 1987). This synergy enhances a firm's competence in distribution channels, geographic location, promotion, and product lines. Marketing synergy is also enjoyed by companies involved in a the acquisition of a similar business if their products or services can be sold through the same or similar channels, in the same or similar manner, or use the same or similar forms of advertising and promotion.

Bradley \& Korn (1981) found that when a firm acquires another with an established national sales force, warehouse system, and promotion program, it can quickly move from a regional to a national focus. An increase in purchasing power can be another consequence of the acquisition of a similar business. The increased purchasing power of the merged firm increases its leverage such that per unit costs should decrease below what either firm could have achieved individually.

Advertising is yet another source of synergy. If sales networks and other promotional devices are transferable, then synergy can result, thereby providing a source of pecuniary gains (Shepherd, 1985). Carlton (1980) even argued that management specialization might dictate the acquisition of firms in industries with similar advertising intensities.

The business relatedness theme and accompanying synergy arguments in the merger and acquisition research also apply to joint ventures. Business similarity between the partners and between the partners and their joint venture have been shown to relate to performance (Balakrishnan \& Koza, 1993; Harrigan, 1988; Koh \& Venkatraman, 1991). Although the findings of these studies are not directly comparable, due to different approaches in how business relatedness was operationalized, two found a positive relationship (Harrigan, 1988; Koh \& Venkatraman, 1991) and one found a negative relationship (Balakrishnan \& Koza, 1993). That is, two studies found that business similarity between partners was positively related to performance, and business similarity between partners and their joint ventures was positively related to performance. The third study found that partner stock returns were higher for parents in dissimilar businesses (Balakrishnan \& Koza, 1993). These contradictory findings can be reconciled in part by the differences in dependent variables and research methods.

In their study on joint ventures, Koh \& Venkatraman (1991) found that when partners were related, and when partners were related to their joint ventures, the ventures had higher gains in abnormal stock returns than did partners involved in unrelated ventures. Using COMPUSTAT tapes and 10-K reports, partners were classified as related if they had at least one of the following characteristics: (1) similar products, markets, or both, (2) similar production technologies, (3) similar science-based research. SIC codes and information from published announcements of joint venture activities were used to classify the partner-joint venture 
relationship. Although the authors reported the relatedness criteria, they did not report the degree of measurement nor detailed decision rules. Thus, it is not known exactly what constituted a related classification. However, Koh \& Venkatraman's (1991) report is consistent with Duncan's (1982) finding that related joint ventures positively and significantly impact average rates of returns.

In a study of strategic alliances, Harrigan (1988) examined business similarity in products, markets, technologies, and competitive activities. She found that relatedness between partners and between partners and their ventures were both positively correlated with success. Because strategic alliances include all types of cooperative ventures, not just joint ventures, it is not known if this finding held for the joint venture subset. Harrigan's (1988) research did not indicate what items were included as competitive activities, nor how relatedness was measured. However, other research suggests that the following items may be important factors in business similarity: geographic areas served, distribution channels, and forms of advertising and promotion (Hopkins, 1987; Thorelli, 1986).

Using three-digit SICs, Balakrishnan \& Koza (1993) measured the distance between the primary businesses of the partner firms. The abnormal stock return for each partner firm was regressed on the distance measure, which yielded positive coefficients at a significance level of .10 or better. The authors concluded that the investors reacted more favorably to joint venture announcements between partners that were in dissimilar businesses. The actual standardized betas were not reported in the article. Using transaction cost theory the authors argue that this favorable response is because joint venture is the most efficient mechanism for coordinating synergistic assets. Thus, investors reward partner firms for choosing the joint venture structure over acquisition. The authors note that the dissimilarity of the partners' businesses may reduce synergy, which, in concert with the coarse dissimilarity measure of 3-digit SICs, may account for the low significance level. Further, the counter influences of distance between partners' businesses suggest that abnormal stock returns may not be an appropriate performance measure when examining similarity in partners' businesses. That is, dissimilarity may be critical in entry mode decisions (e.g., joint venture or acquisition), whereas similarity is critical to performance of the joint venture.

In summary, business similarity appears to be associated with partner motivation and performance. However, there is little consensus on which dimensions of business similarity are important or on which performance measures and research methods are appropriate.

\section{Hypotheses}

Theory suggests that, for the sake of effectiveness, the overlap in business domains should be much less than complete (Thorelli, 1986). However, empirical researchers, arguing from the merger and acquisition literature, suggest that the more related the partners, and the more related the partner and joint venture, the more opportunities there are for strategic compatibility and sharing of techni- 
cal and managerial skills (Harrigan, 1988; Koh \& Venkatraman, 1991). Such relatedness exploits core competencies, leading to economies of scale and scope and efficiency in resource allocation (Rumelt, 1982). Related empirical findings from the merger and acquisition literature support this premise (Bettis, 1981; Montgomery \& Singh, 1984). Similarly, McConnell \& Nantell (1985) argue that joint venture partners are motivated by synergies, and that there must be some common activities or relatedness for synergy to be possible.

As in the merger and acquisition literature (Chatterjee, 1986; Eckbo, 1983; Lubatkin, 1987; Walsh \& Seward, 1990), the overall effect of business similarity on performance is somewhat unclear. One joint venture study found that shareholders responded more favorably to joint ventures between partners in dissimilar businesses (Balakrishnan \& Koza, 1993). The authors of this study argue that dissimilarity positively affects shareholder response (at the time of announcement) because joint ventures are more efficient than acquisitions when it is difficult to appraise the value of another firm's technology and assets. However, the authors also note the importance of synergy in joint ventures. It may be that business similarity has contradictory influences on joint venture performance. On the one hand, initial market costs resulting from firm dissimilarity may be minimized by choosing a joint venture over an acquisition. Thus, shareholders may initially respond favorably to joint ventures between partner firms in dissimilar businesses. However, in the long run joint venture performance depends on synergy and similarity is necessary for synergy to occur. Thus:

Hypothesis 1: The greater the similarity between the joint venture partners' businesses, the higher the achievement of each partner's goals.

Hypothesis 2: The greater the similarity between a partner's business and the joint venture's business, the higher the achievement of the partner's goals.

\section{Research Methods}

Joint venture performance was measured as partner goal achievement. A list of 12 goals was assembled by consolidating the findings and propositions of previous researchers (Berg, Duncan \& Friedman, 1982; Blumenthal, 1988; Contractor \& Lorange, 1988; Harrigan, 1987). The goals used in this study were generated in the following way:

1. Each distinct goal that appeared at least twice in previous research was included.

2. Although the goals of revenues and profits were included in only one previous study on joint ventures, they were included here due to the importance of such goals in any business endeavor. 
3. Space was provided on the survey instrument for write-in goals, to ensure completeness of the goal list.

Business similarity was measured in terms of product and market factors, including technology and manufacturing process. Joint venture theory provided four relevant business similarity dimensions: clientele served, functions performed, territory, and product or service (Thorelli, 1986). Guidance was also drawn from past empirical research on joint and cooperative ventures (Harrigan, 1988; Koh \& Venkatraman, 1991). Because business relatedness is a major issue in the merger and acquisition literature, the approach used in that research was also reviewed (Shelton, 1988). In his article on acquisition strategy, Hopkins (1987) identified key technology and marketing competitive activities - product technology, manufacturing process, distribution channels, and advertising and promotion. These competitive activities are used in this study. In categorizing these dimensions in terms of the input-transformation-output model of organizations, it was noted that although transformation and output were covered in Hopkins' (1987) list, input was not. Therefore, supplier base was included in this study as a competitive activity to address the input stage.

Seven business aspects (geographic areas served, product technology, manufacturing process, product purpose, distribution channels, forms of advertising and promotion, and supplier base) were assessed using five-point Likert scales ranging from (1) no similarity to (5) completely the same. Each partner assessed the similarity between their business and their partner's business, and their business and the joint venture's business, along the seven dimensions.

\section{Sample and Procedures}

Data were collected from executive officers of U.S. firms and subsidiaries directly involved in manufacturing joint ventures. These individuals were identified through telephone conversations with corporate officers at the partner firms as "the most knowledgeable" about particular joint ventures. Identifying joint ventures in the sampling frame was complicated by the fact that firms are not required by law to report their joint venture activity. Therefore, such activity may or may not be reported in a firm's financial statements or by the business press. The Yearbook on Corporate Mergers and Joint Ventures and Corporate Policy was found to be the most comprehensive source of joint venture formation information, since it contains a compilation of all the joint ventures that have been reported in the business press.

In order to reduce non-relevant variance and, thus, make the phenomena under study easier to capture only manufacturing joint ventures created by two U.S. firms or subsidiaries were included in the sampling frame. Also only joint ventures formed between January 1, 1981 and December 31, 1988 were included in the sampling frame. This time frame was chosen in order to create a sufficiently large population from which to draw a sample that would allow for statistical 
analysis. The year of 1988 was used as a cutoff point in order to allow sufficient time for meaningful progress to be made toward goals and to avoid complications of the 1990-91 recession which showed evidence of emerging in late 1989. The process yielded a sample of 72 joint ventures.

Executive officers of the joint venture partners provided consensus responses. That is, participants were asked by telephone and in the survey cover letter to provide information based on the views of the individuals most familiar with the joint venture. As indicated by the respondents, in answer to a direct question in the survey instructions, each response represented the consensus view of two or more of the executive officers most familiar with the joint venture. This response method was used to minimize the potential bias in single responses and to better capture the diversity and complexity inherent in the joint venture structure.

Ninety (90) partner companies, representing 54 joint ventures, were identified as the sampling frame. Ninety-two percent of these companies' executives responded to the survey. The 83 responses provided representation for 50 of the joint ventures. Responses from both partners were received for 33 joint ventures. The sample consisted of joint ventures in SICs 28-38, with the largest number (30 percent) in SIC 36 (electrical and electronic), followed by 24 percent in SIC 28 (chemicals and pharmaceuticals). The sample included thirteen ongoing and 37 dissolved joint ventures, reflecting a dissolution rate of 74 percent among responding firms.

The opportunity to assess the descriptive differences between response and non-response firms was limited because firms are not required to report information on joint ventures separate from their consolidated financial statements. However, response and non-response firms were compared on the basis of the joint venture industry, year of joint venture formation, and percent of ongoing versus dissolved joint ventures. No significant differences were found.

\section{Variables and Measures}

To test the hypotheses, the two independent variables and the partner-goalachievement dependent variable had to be calculated. Respondents rated the importance and achievement of twelve goals pursued through participation in specific joint ventures, using five-point Likert scales. The Likert scale for goal importance was labeled as follows: 1-none, 2-minor, 3-moderate, 4-high, 5-critical. Goals rated as 1 (none) on importance were deleted from further analysis. Thus, accommodation was made for the fact that firms pursue a varying number and mix of goals. The Likert scale for goal achievement was labelled as follows: 1-far short of plan, 2-short of plan, 3-about at plan, 4-exceeds plan, 5-far exceeds plan.

The partner-goal-achievement dependent variable is a composite measure, developed by averaging the achievement ratings of all goals rated to be of minor to critical importance. Goals rated as not important were excluded. The achievement rating of each goal included in the composite measure was weighted by the importance rating. Thus, the higher the importance rating the more weight the 
goal carried in the composite measure. The reliability coefficient alpha for the composite partner goal achievement scale was 0.88 . To provide comparability with prior research, partner satisfaction was measured using a Likert scale ranging from 1, extremely dissatisfied, to 5, extremely satisfied (Beamish, 1987; Blumenthal, 1988; Habib \& Burnett, 1989; Killing, 1983; Schaan, 1983).

Respondents rated the degree of similarity between their business and their partner's business and between their business and their joint venture's business in seven areas. A five-point Likert scale was provided for each measure, with the following labels: 1-no similarity, 2-slightly similar, 3-moderately similar, 4-very similar, 5-completely the same. The business-similarity independent variables are composite measures, developed by averaging the similarity ratings of the individual business domain items. Correlation matrices indicated that similarities in the seven business areas were significantly correlated, suggesting that the individual items could be averaged to produce composite scales. Further, there were several correlations that were .70 or greater, which suggest some items represent much of the same information as other items. As shown in Tables 1 and 2, manufacturing process and product purpose were highly correlated (.70 or greater) with product technology for both the partner-to-partner and partner-to-joint venture comparisons. Therefore, product technology was dropped from the analysis. It may be that the concepts overlap to such an extent that they are indistinguishable. Further, product technology is a more ambiguous concept than are the other business areas, which may have led to difficulty in assessing the item.

In the partner-to-joint venture correlation matrix shown in Table 2, 'Forms of Advertising and Promotion' and 'Distribution Channels' were highly correlated (.80). Therefore, 'Forms of Advertising and Promotion' was dropped from further analysis of business similarity between partners and their joint ventures. Most of the items retained in the business similarity measures represent concrete customer and supplier base dimensions of a firm's business domain. Further, these items cover all three stages of the input-transformation-output model of organizations: input (supplier base), transformation (manufacturing process), and output (geographic areas served, distribution channels, forms of advertising and promotion, and product purpose).

The independent variable used in Hypothesis 1 , business similarity between partners, was computed by averaging respondent ratings on the six business areas of manufacturing process, product purpose, supplier base, geographic area served, distribution channels, and forms of advertising and promotion. The reliability coefficient alpha for this composite measure was .82. Similarly, the independent variable used in Hypothesis 2, business similarity between the partner's and joint venture's businesses, was computed by averaging respondent ratings on the five business areas of manufacturing process, product purpose, supplier base, geographic area served, and distribution channels. The reliability coefficient alpha for this composite measure was .84 . 
Table 1

Means, Standard Deviations, and Correlations for Business Similarity Between Partners ${ }^{\mathrm{a}}$

Variables

Means s.d.

2

3

4

5

1. Geographic Area Served

$3.20 \quad 1.24$

2. Product Purpose

$2.50 \quad 1.41 \quad .40 * *$

3. Product Technology

$2.26 \quad 1.15 \quad .29 *$

$.74 * * *$

4. Distribution Channels

$2.12 \quad 1.26$

$2.09 \quad 1.12$

$.39 * * * \quad .48^{* * *} \quad .43^{* *}$

5. Forms of Advertising and Promotion

$.35 *$

$.46 * * * \quad .38 * * \quad .61 * * *$

6. Manufacturing Process

7. Supplier Base

$1.94 \quad 1.18$

.21

$1.90 \quad 1.17$

.22

$.64 * * * \quad .74 * * * \quad .37 * *$

Partner Goal Achievement

$2.59 \quad .90$

Partner Satisfaction

$2.72 \quad 1.34$

.90
.34

$.24 *$

$.49 * *$

$.47^{* * *} \quad .31^{*}$

$.36 * *$

${ }^{2} \mathrm{~N}=82$ partner respondents for the means and standard deviations; $\mathrm{N}=50$ joint ventures for the inter-correlations (sample restricted to JVs in order to balance representation, due to the fact that for some JVs both partners responded and for other JVs only one partner responded). Correlations .70 and above are underlined.

${ }^{*} \mathrm{p}<.05$

$* * p<.01$

$* * * p<.001$ 
Table 2

Means, Standard Deviations, and Correlations for Business Similarity

Between Partners and Their Joint Ventures

\begin{tabular}{|c|c|c|c|c|c|c|c|c|c|}
\hline Variables & Means & s.d. & 1 & 2 & 3 & 4 & 5 & 6 & 7 \\
\hline 1. Geographic Area Served & 3.51 & 1.34 & & & & & & & \\
\hline 2. Product Purpose & 2.90 & 1.46 & $.53 * * *$ & & & & & & \\
\hline 3. Product Technology & 2.79 & 1.34 & $.44 * * *$ & $.73 * * *$ & & & & & \\
\hline 4. Distribution Channels & 2.74 & 1.50 & $.52 * * *$ & $.68 * * *$ & $60 * * *$ & & & & \\
\hline 5. Forms of Advertising and Promotion & 2.51 & 1.38 & $.45^{* * *}$ & $.63 * * *$ & $.55 * * *$ & $.80 * * *$ & & & \\
\hline 6. Manufacturing Process & 2.51 & 1.43 & $.27^{*}$ & $.56 * * *$ & $.70 * * *$ & $.49 * * *$ & $.38 * * *$ & & \\
\hline 7. Supplier Base & 2.49 & 1.36 & $.37 * * *$ & $.65 * * *$ & $.66 * * *$ & $.57 * * *$ & $.57 * * *$ & $.64 * * *$ & \\
\hline Partner Goal Achievement & 2.59 & .90 & $.23^{*}$ & .05 & .16 & .13 & .10 & .06 & $.23^{*}$ \\
\hline Partner Satisfaction & 2.72 & 1.34 & .13 & -.01 & -.06 & -.06 & .04 & .06 & .05 \\
\hline 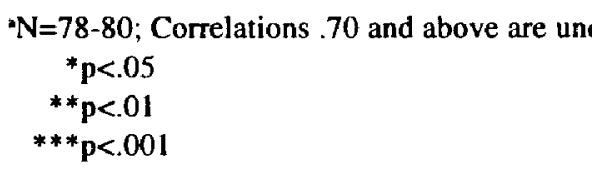 & & & & & & & & & \\
\hline
\end{tabular}




\section{Analysis}

The literature suggests that self-reported data collected at one point in time is subject to common method variance bias. A frequently used procedure to test for common method variance bias is Harman's one-factor test (Podsakoff, Todor, Grover \& Huber, 1984). This technique suggests that if a substantial amount of common method variance is present, either (1) a single factor will emerge from a factor analysis, or (2) one general factor will account for the majority of the covariance (Podsakoff \& Organ, 1986).

The variables in this study were entered into a factor analysis, which yielded two clearly distinct factors and no general factor. The results of this analysis is reported in Table 3. While this analysis does not rule out the possibility of samesource, self-report biases, it does suggest that common method variance does not explain the findings of this study.

Table 3

Harman's One-factor Test for Common Method Variance Bias

\begin{tabular}{lcc}
\hline Variables & Factor 1 & Factor 2 \\
\hline Partner Goal Achievement & .91764 & .17322 \\
Partner Satisfaction & .94134 & .05227 \\
Business Similarity Between Partners & .25128 & .72392 \\
Business Similarity Between Partners and JV & -.03151 & .85624 \\
Eigenvalues & 1.98263 & 1.09963 \\
Percentage of variance explained & 49.6 & 27.5 \\
\hline
\end{tabular}

${ }^{2} n=75$

Descriptive statistics for goal importance and goal achievement indicate that partners pursue a variety of goals (see Table 4). Further, when examining the goals which were of critical importance (rating=5) it was found that partners still pursued a variety of goals, contrary to having one primary purpose (such as market access or technology transfer) as the theoretical literature on joint venture formation suggests. The goals most frequently pursued as "critically important" were 'Product or technology development' at 38 percent, followed by 'Acquisition of technical knowledge/skills' at 30 percent, 'Market or product expansion' at 22 percent, and 'Market entry' at 22 percent.

Frequencies of the two composite measures of business similarity between partners and business similarity between partners and their joint ventures are presented in Table 5. Based on the composite scale, 60 percent of the respondents reported that their business was at least moderately similar to their joint venture's business, and 40 percent reported that their business was at least moderately similar to their partner's business. 
Table 4

Descriptive Statistics for Goal Importance and Achievement

\begin{tabular}{llcll} 
Goal & N & $\begin{array}{c}\text { Mean Goal } \\
\text { Importance }\end{array}$ & Goal & Mean Goal \\
\hline Product or technology development/acquisition & 75 & 4.04 & Acquisition of technical knowledge/skills & Nemt \\
Market or product expansion & 72 & 3.99 & Product or technology development/acquisition & 77 \\
Market entry & 71 & 3.96 & Vertical integration & 2.91 \\
Profits & 73 & 3.89 & Overcome government barriers \\
Acquisition of technical knowledge/skills & 76 & 3.88 & Spread financial risk \\
Revenues & 70 & 3.64 & Increase available capital \\
Economies of scale or production efficiency & 63 & 3.54 & Economies of scale or production efficiency \\
Spread financial nisk & 69 & 3.48 & Manage competition \\
Manage competition & 66 & 3.33 & Market entry \\
Increase available capital & 51 & 3.22 & Market or product expansion \\
Vertical integration & 53 & 3.00 & Revenues \\
Overcome government barriers & 30 & 2.70 & Profits
\end{tabular}

Goal

Critically Important Goals (rating $=5$ )

\begin{tabular}{llc}
\hline Product or technology development & 30 & 38 \\
Acquisition of technical knowledge/skills & 24 & 30 \\
Market or product expansion & 17 & 22 \\
Market entry & 17 & 22 \\
Profits & 12 & 15 \\
Economies of scale or production efficiency & 10 & 13 \\
Revenues & 8 & 10 \\
Spread financial risk & 7 & 9 \\
Vertical integration & 7 & 9 \\
Manage competition & 6 & 8 \\
Increase available capital & 4 & 5 \\
Overcome government barriers & 1 & 1
\end{tabular}


Table 5

Descriptive Statistics for Calculated Business Similarity Independent Variables

Frequencies

\begin{tabular}{|c|c|c|c|c|}
\hline \multirow{2}{*}{$\begin{array}{l}\text { Degree of } \\
\text { Business Similarity }\end{array}$} & \multicolumn{2}{|c|}{ Partner-to-Partner ${ }^{2}$} & \multicolumn{2}{|c|}{ Partner-to-Joint Venture } \\
\hline & Percent & Cum. Percent & Percent & Cum. Percent \\
\hline 5-Completely the Same & 2 & 2 & 5 & 5 \\
\hline 4-Very Similar & 12 & 14 & 26 & 31 \\
\hline 3-Moderately Similar & 20 & 40 & 29 & 60 \\
\hline 2-Slightly Similar & 43 & 83 & 26 & 86 \\
\hline 1-No Similarity & 17 & 100 & 14 & 100 \\
\hline
\end{tabular}

$\mathrm{N}=82$

${ }^{b} \mathrm{~N}=80$

Means, Standard Deviations, and Correlations

\begin{tabular}{lcrrrr}
\hline Variables & Means & s.d. & 1 & 2 & $\begin{array}{c}\text { Partner } \\
\text { Goal Ach. }\end{array}$ \\
\hline 1. Partner-to-Partner & 2.40 & .99 & & & \\
2. Partner-to-JV & 2.83 & 1.10 & $.32^{* *}$ & & \\
Partner Goal Achievement & 2.59 & .90 & $.24^{*}$ & .13 & \\
Satisfaction & 2.65 & 1.30 & $.20^{*}$ & .04 & $.77^{* * *}$ \\
\hline
\end{tabular}

${ }^{*} \mathrm{p}<.05$

$* * \mathrm{p}<.01$

$* * * p<.001$

Descriptive statistics for the business similarity independent variables are also presented in Table 5. Regression analysis was used to test the hypotheses. The regression models for partner goal achievement using the business similarity independent variables are presented in Table 6. Each hypothesis is tested independently of each other in regression Models 1 and 2. In Model 3, the business similarity independent variables, along with an interaction term, are combined into a single multiple regression model to more fully examine the business similarity concept in explaining performance.

Hypothesis 1, the greater the similarity between the partners' businesses the higher the average achievement on the set of partner goals, was supported by the regression analysis in Table 6 . That is, the standardized beta was positive and the F statistic for Model 1 was significant at the .05 level. Hypothesis 2 , the greater the similarity between the partner's and the joint venture's businesses the higher the average achievement on the set of partner goals, was not supported by the regression analysis. That is, the standardized beta was positive as predicted, however, the F statistic for Model 2 was not significant at the .05 level. 
Table 6

Results of Regression Analysis for Partner Goal Achievement Using Business Similarity Variables ${ }^{\mathrm{a}}$

\begin{tabular}{|c|c|c|c|c|}
\hline \multicolumn{2}{|c|}{ Variables } & \multirow{2}{*}{$\frac{\text { Model } 1}{.23^{*}}$} & \multirow[t]{2}{*}{ Model 2} & \multirow[t]{2}{*}{ Model 3} \\
\hline 1. & Partner-to-Partner & & & \\
\hline 2. & Partner-to-Joint Venture & & .13 & -.29 \\
\hline \multicolumn{4}{|c|}{$\begin{array}{l}\text { 3. Partner-to Partner by Partner-to-Joint Venture } \\
\text { (Interaction Term) }\end{array}$} & $.52 * *$ \\
\hline $\mathbf{R}^{2}$ & & .05 & .02 & .12 \\
\hline Ad & usted $\mathrm{R}^{2}$ & .04 & .00 & .09 \\
\hline $\mathbf{F}$ & & $4.52 *$ & 1.36 & $5.29 * *$ \\
\hline
\end{tabular}

$\mathrm{N}=83$

$* \mathrm{p}<.05$

$* * \mathrm{p}<.01$

After testing each business similarity hypothesis an interaction term was computed and combined with the business similarity independent variables into a single multiple regression model for partner goal achievement. This analysis yielded a model that explained 12 percent of the variance in partner goal achievement, with the interaction term being the only significant variable in the model. Thus, suggesting that business similarity between partners and business similarity between a partner and its joint venture have a multiplicative and positive effect on partner goal achievement.

The same regression analysis (Table 7) was performed with the supplemental dependent variable of partner satisfaction as with partner goal achievement. The pattern of influence was the same as with the partner goal achievement performance variable. However, the F statistics were not significant at the .05 level.

Table 7

Results of Regression Analysis for Partner Satisfaction Using Business Similarity Variables

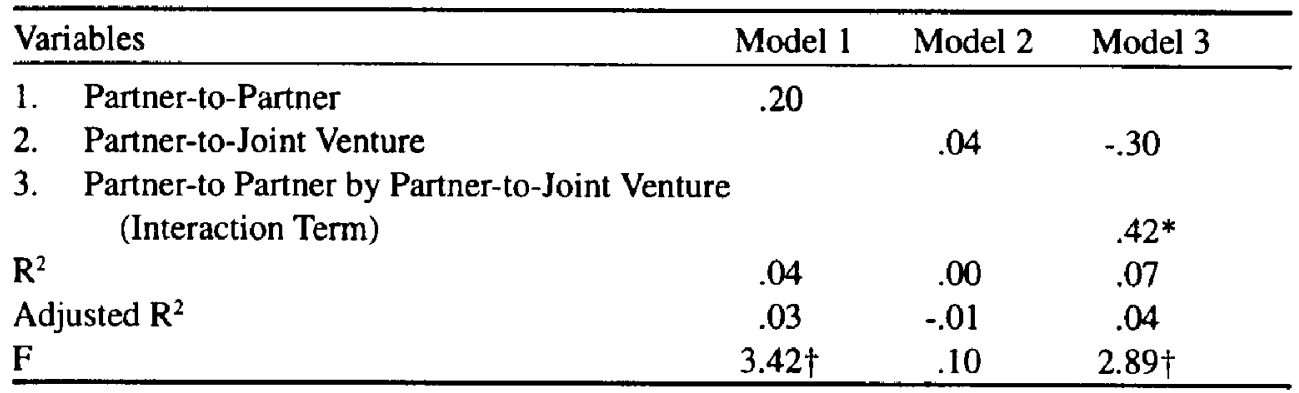

${ }^{\mathrm{N}} \mathrm{N}=83$

$\dagger \mathrm{p}<10$

*p<.05

**p< $<01$ 


\section{Discussion}

Business similarity between partners was found to positively relate to partner goal achievement. This research, therefore, provides support for the applicability of the business relatedness concept in the joint venture environment. In addition, this study offers a partial reconceptualization of the business relatedness concept in the joint venture environment by identifying key aspects of business similarity: geographic areas served, supplier base, distribution channels, and forms of advertising and promotion. Further, the traditional business relatedness areas in the merger and acquisition literature of product technology, manufacturing process, and product purpose were not found to significantly relate to joint venture performance. Finally, this study suggests that business similarity between partners and business similarity between a partner and its joint venture have positive multiplicative effects on performance.

Joint ventures are motivated by synergies, and relatedness is a necessary condition for synergy to be possible (McConnell \& Nantell, 1985). Such relatedness affords the ability to exploit core competencies, leading to economies of scale and scope and efficiency in resource allocation (Rumelt, 1982). The findings of our research complement two past studies (Harrigan, 1988; Koh \& Venkatraman, 1991) that also found a positive relationship between business similarity and performance. Our confidence in these findings is amplified by the fact that each study used a different method of measuring business similarity and employed a different performance measure. The positive relationship between business similarity and performance was strong enough and consistent enough that all three measuring schemes captured the phenomena.

In a comparative analysis it was found that business similarity between partners explained only five percent of the variance in partner goal achievement, and business similarity between a partner and their joint venture did not significantly affect partner goal achievement. However, when combined into a single multiple regression model with the inclusion of an interaction term, the $R^{2}$ increased to 12 percent, with the interaction term being the only significant variable in the model. For executives in search of joint venture partners the implication is clear: Seek a partner similar to yourself. Seek a partner whose operational and competitive situations you understand and to which you can relate.

Merger and acquisition researchers have measured business relatedness by relying on secondary data. Using a variety of decision rules, they classified mergers into categories of relatedness. This study suggests that self-assessment by partner firms is also possible, and it is better, because it allows for the incorporation of situation specific nuances that researcher assessment cannot adequately capture. This is especially important given the existence of two organizational levels (i.e., corporate and business) at which a joint venture can be created and managed, which makes the relevant business domain difficult for researchers to identify and assess. Self-assessment allows the degree of business similarity to be 
captured, which is more reflective of reality than are traditional categorical classification schemes. Business similarity varies in degree and is not captured in the traditional research dichotomous choice of related or unrelated. Prospective joint venture partners should, therefore, consider assessing mutual similarities that include intangible as well as objective factors. Executives' aspirations for their own firm as well as for the contemplated joint venture may provide critical clues to the enduring compatibility of superficially enamored partner candidates.

Finally, in comparing the regression analyses using the performance variable of partner goal achievement with the supplemental dependent variable of partner satisfaction, the non-significant relationship between similarity and partner satisfaction offers further evidence that partner goal achievement is a better performance measure than is partner satisfaction. The non-significance for partner satisfaction could be explained by the fact that satisfaction is affected by many more factors than performance alone, such as JV duration and survival, and environmental factors (Hatfield \& Pearce, 1994).

This study addressed two-partner, for-profit, U.S. domestic joint ventures in the manufacturing sector. Thus, generalizability to international joint ventures, service joint ventures, or joint ventures with more than two partners or non-profit partner(s) must be done with caution. The limited research on joint venture performance necessitated extensive measure and scale development. Although an attempt was made to base measures on previous research, there was little consensus in the literature on key dimensions. This was a cross-sectional study utilizing managerial assessments. Thus, the possibility of recollection biases exits, despite the precaution of soliciting perceptions from multiple individuals at each partner firm and the negative results of the common method bias test.

The support for the hypotheses that the research produced, and the compatibility of the findings when viewed as a group of related ideas, have a useful implication for practicing managers. Executives searching for joint venture partners should look for compatibility not only in terms of needs that both prospective partners hope to satisfy through the success of the venture but also in terms of the prospective partners' business domains. Our research results suggest that when partners' business similarity is at an initially high level, the probability of the success of the joint venture is improved. Similarities between partners in their supplier base, their forms of advertising and promotion, their distribution channels, and the geographic areas that they serve appear to be important.

A logical extension of this finding is the notion that partners should also seek opportunities to create overlaps between the joint venture's business domain with their own, particularly in the areas of supplier base and geographic area served. These common activities can provide a basis from which to create synergies in operations, such as the fuller utilization of shared warehouse and distribution facilities, the benefits from quantity discounts by combining orders for suppliers, and the exchange of technical and managerial skills that produce economies of scope and the exploitation of core competencies. 
The findings of this study, in concert with subsequent refinements and extensions, will contribute to the further development of a practitioner-worthy theory of joint ventures. This theory will need to accommodate: (1) the areas of business similarity that are critical in joint venturing, (2) the interaction effect on performance of business similarity between partners and business similarity between a partner and its joint venture, (3) the diverse goals partner firms pursue simultaneously, and (4) the need for joint venture performance measures, such as partner goal achievement, that are precise yet broad enough to include partners' nonfinancial objectives for joint venturing

\section{References}

Allen, M.G., Oliver, A.R., \& Schwallie, E.H. (1981). The Key to Successful Acquisitions. The Joumal of Business Strategy 2 (2), Fall: 14-24.

Anderson, E. (1990). Two firms, one frontier: On assessing joint venture performance. Sloan Management Review, 31 (2): 19-30.

Balakrishnan, S., \& Koza, M.P. 1993. Information asymmetry, adverse selection and jointventures. Journal of Economic Behavior and Organization. 20: 99-117.

Beamish, P.W. (1987). Joint ventures in LDCs: Partner selection and performance. Management International Review. 27 (1): 23-37.

Berg, S.V., Duncan, J., \& Friedman, P. (1982). Joint venture and corporate innovation. Cambridge, MA: Oelgeschlager, Gunn and Hain Publishers, Inc.

Bettis, R.A. (1981). Performance differences in related and unrelated diversified firms. Strategic Management Journal, 2 (4): 379-392.

Blumenthal, J.F. (1988). Strategic and organizational conditions for joint venture formation and success. Dissertation: University of Southern California.

Bradley, J.W., \& Korn, D.H. (1981). Acquisition and Ccorporate development. Lexington, MA: Lexington Books: 17-27.

Carlton, H.S. (1980). An empirical study of merger motives. ET.C. study, 1-97.

Chatterjee, S. (1986). Types of synergies and economic value: The impact of acquisitions on merging and rival firms. Strategic Management Journal. 7: 119-139.

Contractor, F.J., \& Lorange, P. (1988). Why should firms cooperate: The strategy and economics basis for cooperative ventures. In F.J. Contractor \& P. Lorange (Eds.), Cooperative strategies in international business. Lexington, MA: Lexington Books, 3-30. 
Dess, G.G., \& Robinson, Jr., R.B. (1984). Measuring organizational performance in the absence of objective measures: The case of the privately-held firm and conglomerate business unit. Strategic Management Journal 5 (3): 265-273.

Duncan, J.L. (1982). Impacts of new entry and horizontal joint ventures on industrial rates of return. Review of Economics and Statistics. 64 (2): 339-342.

Eckbo, B. (1983). Horizontal mergers, collusion and stockholder wealth. Journal of Financial Economics. 11 (1-4): 241-273.

Fahey, L., \& Christensen, H.K. (1986). Evaluating the research on strategy content. 1986 Yearly Review of the Journal of Management. 12 (2): 167-183.

Fisher, F.M. (1987). Horizontal mergers: Triage and treatment. Journal of Economic.Perspectives, Fall: $23-40$.

Geringer, J.M., \& Hebert, L. (1991). Measuring performance of international joint ventures. Journal of International Business Studies. 22 (2): 249-263.

Gomes-Casseres, B. (1987). Joint venture instability: Is it a problem? Columbia Journal of World Business. XXII (2): 97-104.

Gomes-Casseres, B. (1989). Joint ventures in the face of global competition. Sloan Management Review, 30 (3): 17-26.

Gulati, R. (1995). Does familiarity breed trust? The implications of repeated ties for contractual choice in alliances. Academy of Management Joumal. 38: 85-112.

Habib, G.M., \& Burnett, J.J. (1989). An assessment of channel behavior in an alternative structural arrangement: The international joint venture. International Marketing Review, $6(3): 7-21$.

Harrigan, K.R. (1987). Managing joint ventures-Part I. Management Review. 76 (2): 24-42.

Harrigan, K.R. (1988). Strategic alliances and partner asymmetries. Management International Review, 28: 53-72.

Hatfield, L., \& Pearce II, J.A. (1994). Goal Achievement and Satisfaction of Joint Venture Partners. Journal of Business Venturing, 9 (5): 423-449.

Hennart, J.F., \& Reddy, S. (1997). The choice between mergers/acquisitions and joint ventures: The case of Japanese investors in the United States. Strategic Management Journal. 18 (1): 1-12.

Hopkins, H.D. (1987). Acquisition strategy and the market position of acquiring firms. Strategic Management Journal, 8 (6): 535-547. 
Inkpen, A.C., \& Beamish, P.W. (1997). Knowledge, bargaining power, and the instability of international joint ventures. Academy of Management Review, 22 (1): 177-202.

Kanter, R.M. (1989). Becoming PALs; Pooling, allying, and linking across companies. Academy of Management Executive, 3 (3): 183-193.

Kanter, R.M., Richardson, L., North, J., \& Morgan, E. (1991). Engines of progress: Designing and running entrepreneurial vehicles in established companies; the new venture process at Eastman Kodak, 1983-1989. Joumal of Business Venturing. 6 (1): 63-82.

Killing, J. (1983). Strategies for Joint Venture Success. CBS Educational and Professional Publishing a Division of CBS Inc.: Praeger Publishers.

Kogut, B. (1988). Joint ventures: Theoretical and empirical perspectives. Strategic Management Joumal. 9 (4): 319-332.

Koh, J., \& Venkatraman, N. (1991). Joint venture formations and stock market reactions: An assessment in the information technology sector. Academy of Management Journal. 34 (4): 869-892.

Kusewitt, Jr., J.B. (1985). An exploratory study of strategic acquisition factors relating to performance. Strategic Management Journal, 6: 151-169.

Levine, J.B., \& Bryne, J.A. (1986), Corporate odd couples. Business Week, July 21: 100105.

Lewin, A.Y., \& Minton, J,W, (1986), Determining organizational effectiveness: Another look, and an agenda for research. Management Science, 32 (5): 514-538.

Lubatkin, M. (1987). Merger strategies and stockholder value. Strategic Management Journal. 8 (1): 39-53.

Madhavan, R., \& Prescott, J.E. (1995). Market value impact of joint ventures: The effect of industry information-processing load. Academy of Management Journal. 38 (3): 900-915.

McConnell, J.J., \& Nantell, T.J. (1985). Corporate combinations and common stock returns: The case of joint ventures. The Joumal of Finance, 40 (2): $519-536$.

Montgomery, C.A., \& Singh, H. (1984). Diversification strategy and systemic risk. Strategic Management Journal. 5 (2): 181-191.

Moose, S., \& Richard, J.D. (1988). Roundtable - Managing the trade-offs in corporate development. Mergers and Acquisitions. 23: 3, November: 18-31.

Mowery, D.C., Oxley, J.E., \& Silverman, B.S. (1996). Strategic alliances and interfirm knowledge transfer. Strategic Management Joumal. 17 (Winter Special Issue): 77-91. 
Mueller, D.C. (Ed.). (1980). The determinants and effects of mergers - an international comparison. Cambridge, MA: Oelgeschlager, Gunn and Hain Publishers.

Park, S.H., \& Russo, M.V. (1996). When competition eclipses cooperation: An event history analysis of joint venture failure. Management Scjence. 42 (6): 875-890.

Pearce, R.J. (1997). Toward Understanding Joint Venture Performance and Survival: A bargaining and influence approach to transaction cost theory. Academy of Management Review.22 (1): 203-225.

Podsakoff, P.M., Todor, W.D., Grover, R.A., \& Huber, V.L. (1984). Situational moderators of leader reward and punishment behaviors: Fact or fiction? Organizational Behavior and Human Performance. 34: 21-63.

Podsakoff, P.M., \& Organ, D.W. (1986). Self-reports in organizational research: Problems and prospects. Journal of Management. 12 (4): 531-544.

Porter, M.E. (1987). From competitive advantage to corporate strategy. Harvard Business Review, 65 (3): 43-59.

Rock, M.L. (Ed.). (1987). The Mergers and Acquisitions Handbook, New York: McGrawHill.

Rosenthal, R. (1991). Replication in behavioral research. In J.W. Neuliep (ed.), Replication Research in the Social Sciences. Newbury Park, CA: Sage Publications, pp. 130.

Rumelt, R.P. (1982). Diversification strategy and profitability. Strategic Management Journal. 3 (4): 359-369.

Schaan, J. (1983). Parent control and joint venture success: The Case of Mexico. Unpublished doctoral dissertation. Ontario, Canada: University of Western Ontario.

Schillaci, C.E. (1987). Designing successful joint ventures. The Journal of Business Strategy, 8 (2): 59-63.

Shelton, L.M. (1988). Strategic business fits and corporate acquisition: empirical evidence. Strategic Management Journal. 9 (3): 279-287.

Shepherd, W.G. (1985). The Economics of Industrial Organization. NJ: Prentice Hall.

Singh, H., \& Montgomery, C.A,. (1987). Corporate acquisition strategies and economic performance. Strategic Management Journal, 8: 377-386.

Thorelli, H.B. (1986). Networks: Between markets and hierarchies. Strategic Management Joumal. 7 (1): 37-51. 
Walsh, J.P., \& Seward, J.K. (1990). On the efficiency of internal and external corporate control mechanisms. Academy of Management Review. 15 (3): $421-458$.

Weston, J.F., \& Chung, K.S. (1983). Do mergers make money? Mergers and Acquisitions, 18: (3): $40-48$.

Jack Pearce is the Endowed Chair in Strategic Management and Entrepreneurship at Villanova University. He has authored 70 articles, 120 refereed professional papers, and 25 books, including Formulation and Implementation of Competitive Strategy, Irwin, 1997. He was the first Chairman of the Academy of Management's Entrepreneurship Division and a past President of the Southern Management Association. His executive development programs and business consulting emphasize mission statement development, industry analysis, strategy formulation, business turnaround, and process reengineering.

Louise Hatfield is an Associate Professor of Strategic Management at the John L. Grove College of Business, Shipppensburg University. She has thirteen years of business management experience. She was awarded her Ph.D. in 1993 and has published 12 papers on joint ventures. 